International Journal of Modern Anthropology

Int. J. Mod. Anthrop. 2020. Vol. 2, Issue 14, pp: 318 - 336

DOI: http://dx.doi.org/10.4314/ijma.v2i14.5

Available online at: www.ata.org.tn \& https://www.ajol.info/index.php/ijma

\title{
The Iberian-Guanche rock inscriptions at La Palma Is.: all seven Canary Islands (Spain) harbour these scripts
}

\author{
Antonio Arnaiz-Villena ${ }^{*}$, Fabio Suárez-Trujillo, Valentín Ruiz-del-Valle ${ }^{1}$, Adrián \\ López-Nares ${ }^{1}$, Felipe Jorge Pais-Pais ${ }^{2}$ \\ ${ }^{1}$ Department of Inmunology, University Complutense, School of Medicine, Madrid, Spain \\ ${ }^{2}$ Director of Museo Arqueológico Benahoarita. C/ Adelfas, 3. Los Llanos de Aridane, La Palma, Islas Canarias. \\ *Corresponding author: Antonio Arnaiz-Villena. Departamento de Inmunología, Facultad de Medicina, Universidad \\ Complutense, Pabellón 5, planta 4. Avd. Complutense s/n, 28040, Spain. \\ E-mail: arnaizville@hotmail.com ; aarnaiz@med.ucm.es; Web page:http://chopo.pntic.mec.es/biolmol/
}

(Received 15 October 2020; Accepted 5 November 2020; Published 20 November 2020)

\begin{abstract}
Rock Iberian-Guanche inscriptions have been found in all Canary Islands including La Palma: they consist of incise (with few exceptions) lineal scripts which have been done by using the Iberian semi-syllabary that was used in Iberia and France during the $1^{\text {st }}$ millennium $\mathrm{BC}$ until few centuries $\mathrm{AD}$. This confirms First Canarian Inhabitants navigation among Islands. In this paper we analyze three of these rock inscriptions found in westernmost La Palma Island: hypotheses of transcription and translation show that they are short funerary and religious text, like of those found widespread through easternmost Lanzarote, Fuerteventura and also Tenerife Islands. They frequently name "Aka" (dead), "Ama" (mother godness) and "Bake" (peace), and methodology is mostly based in phonology and semantics similarities between Basque language and prehistoric Iberian-Tartessian semi-syllabary transcriptions. These Iberian-Guanche scripts are widespread in La Palma usually together with spiral and circular typical Atlantic motifs which are similar to these of Megalithic British Isles, Brittany (France) and Western Iberia. Sometimes linear incise Iberian-Guanche inscriptions are above the circular ones (more recent) but they are also found underneath (less recent). The idea that this prehistoric Iberian semi-syllabary was originated in Africa and/or Canary Islands is not discarded. It is discussed in the frame of Saharian people migration to Mediterranean, Atlantic (i.e.: Canary Islands) and other areas, when hyperarid climate rapidly established. On the other hand, an Atlantic gene and possibly linguistic and cultural pool is shared among people from British Isles, Brittany (France), Iberia (Spain, Portugal), North Africa and Canary Islands.
\end{abstract}

Keywords: La Palma, Iberian-Guanche, Latin, Inscriptions, Iberian, Celts, Sahara, Africa, Garafia, Santo Domingo, Canary Islands, Lybic British, Brittons, Basque, Irish, Lybic Canarian, Palmeses, Benahoaritas, Awaritas, Tricias, Prehistory, Guache, Tartessian. 


\section{Introduction}

Juan Brito Martín, a local artist and independent archaeologist, was exhibiting since 1980 at the Arrecife Museum in Lanzarote Island drawings taken from inscriptions found on island rocks of unknown affiliation; they were classified by Pichler as "Latin" or "Libyc-Canarian" (Pichler 1995; 2003) and were also found at Fuerteventura Island (Canary Islands). However, they were usually made by incised linear scripts that lack Q, $\mathrm{H}, \mathrm{P}$, and $\mathrm{T}$, frequent Latin letters, and translation into Latin has not been possible (Pichler 1995; 2003). In the beginning of the $21^{\text {st }}$ century, we proposed an Iberian transcription and translation hypothesis, since the writings were almost identical to those of the Iberian semi-syllabary that was used in Iberia and southern France during the first millennium BC (Fig. 1).

We proposed the name of Iberian-Guanche instead of "Latin" for them and they were mostly religious and funerary (Arnaiz-Villena and Alonso-García 2001; Arnaiz-Villena et al. 2001). This type of linear incision writing has been found in the seven main Canary Islands and has been able to go unobserved probably because Canary Islands, except Lanzarote and Fuerteventura, are wet and covered with abundant vegetation and rock lichens (Arnaiz-Villena et al. 2019a; 2019b) which had making them not easily visible. The people who wrote Iberian-Guanche inscriptions seem to be Canarian aboriginal inhabitants and not visitors. The genes of present and past Canarians are difficult to assign only to North Africa because gene flow between North Africa and Iberia has existed since prehistoric times and it is difficult to distinguish the Iberian and North African gene profiles attributed to Canarians (Arnaiz-Villena et al. 2019a; 2019b).

The "Palmeses", inhabitants of the island of La Palma (as they are named according to the texts of the Spanish Conquest) (Fig. 2), have also been called Benahoaritas and Awaritas, neologisms coined by historians after 1842 (Berthelot) and adapted to the hypothesis presumed of an exclusively African origin of La Palma aborigines (Hernandez-Perez 1972). There have been different theories about La Palma. First Inhabitants (and Canarians) origin (including from Europe) that, given the complexity of the subject in space and time, and due to political interests on different times, we consider strictly hypothetical and secondary for our study. 
Also, very old physically measured objective dates have not been found at La Palma, but it does not indicate that they have been exhaustively searched, nor that they will not be found in the future (Pais-Pais 2019; 2020). A very complete summary of La Palma Island anthropology and many of the rock inscriptions recorded in La Palma Island are found in Pais-Pais 2019.

\begin{tabular}{|c|c|c|c|c|c|c|c|c|c|}
\hline$\stackrel{\text { berian }}{\longrightarrow}$ & & $\stackrel{\text { Tartessian }}{\longleftarrow}$ & & $\begin{array}{c}\text { Anciont } \\
\text { Grealk }\end{array}$ & $\stackrel{\text { Iberian }}{\longrightarrow}$ & & Tartessian & & \\
\hline$R D P P$ & $a$ & A4 & $k \nless$ & $\triangle A$ & $P \Gamma$ & $b i$ & $?$ & ) $1 p$ & $\eta_{p}$ \\
\hline SEE & e & 干F( & $\lambda$ & 习 & X** & bo & $W \infty *$ & & \\
\hline$\because N N$ & 2 & यम (x) & $z$ & 21 & $\square$ & bu & $\square$ & & \\
\hline $\mathrm{HH}$ & 0 & $0 \diamond 9$ & 0 & 0 & $X$ & ta & $+x+$ & $F \times t$ & $T t$ \\
\hline Аヘ个 & $u$ & 4 个 $\ddot{\text { i? }}$ ? & YY & YV & $\theta \otimes D(1$ & re & $(1) \otimes \otimes$ & $\oplus$ th & $\oplus$ th \\
\hline$\mu r \Lambda$ & l & 1 & L & $1 \mathrm{~J}$ & $\Psi \psi \Psi \psi$ & $K_{i}$ & 比目明日 & 目月 & 日h \\
\hline ১৭২০১4 & $r$. & 490 & 4 & 49 & vшщ & to & 令上 & & \\
\hline MM & $S$ & $M M M$ & $w / 2$ & $M$ & $\oplus \Delta \Delta \Delta$ & tur & $\Delta \Delta V$ & $\Delta \Delta$ & $\Delta d$ \\
\hline$\xi \leqslant s$ & 5. & 丰些么 & 平 & 手 $x$ & $A A \wedge$ & $c a$ & & 19 & 419 \\
\hline YYVY Y & $m$ & $\xi \leqslant$ & \$.y & $M$ & $<\mathbb{C} c<\leqslant$ & ke & )| 1 DDac(个 & $\psi k$ & $\times 1 k$ \\
\hline$N N$ & $m$ & ทYy (অ) & $y$ & $y$ & $f 4 \wedge 5$ & $k i$ & $1 Z(2 N=$ & & \\
\hline & ba & & & & 8 & co & WZ & & \\
\hline & be & ry & & & & $\mathrm{cu}$ & & $\varphi_{q}$ & $\phi_{q}$ \\
\hline
\end{tabular}

Fig. 1 Iberian-Tartessian semi-syllabary discovered by Manuel Gómez Moreno (Gómez Moreno 1949; 1962)

La Palma Island incise linear rock scripts are similar to those found at Lanzarote and Fuerteventura, and other Canary Islands. It was evident that we are dealing with Iberian semi-syllabic inscriptions in the Canary Islands, which we transcribed according to the Iberian semi-syllabary described by Manuel Gómez Moreno (Fig. 1). These Iberian-Guanche rock inscriptions have been found in all the Canary Islands, which indicate that Canarian aborigines did navigate. 
The Iberian writing found apparently has an Iberian-Levantine character and not a Southeast (Tartessian) one. This type of writing in Canary Islands also has the peculiarity that lines of contiguous signs used to be often written together. This characteristic is also found in the Libyc-Berber writings of Canary Islands, which also tend to join letter characters when convenient. It is a Canarian characteristic compared to the Libyc-Berber writing found in the African continent (Arnaiz-Villena and AlonsoGarcía 2001).

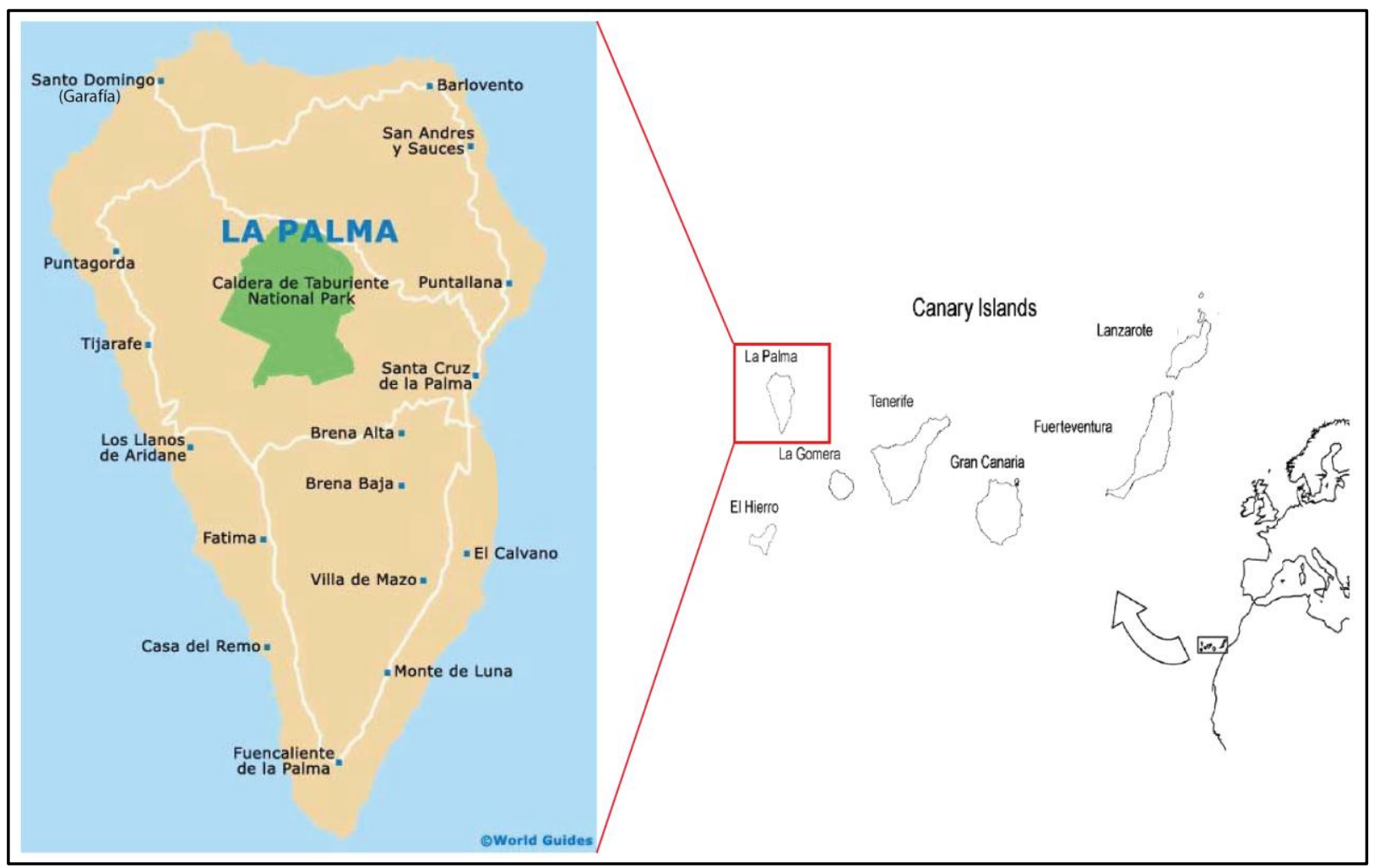

Fig. 2 Map of the Canary Islands and their placing regarding the coasts of Europe and Africa, with an enlargement of La Palma Island.

Iberian inscriptions have been found in all seven 7 Canary Islands (Arnaiz-Villena et al. 2019b). 
A

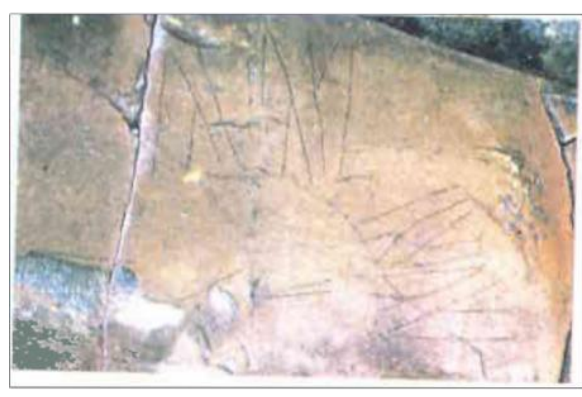

B

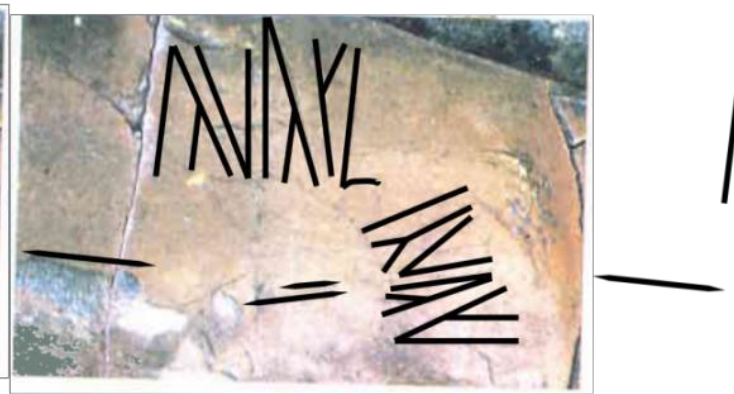

C

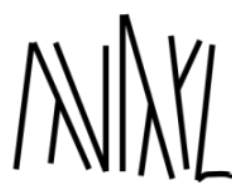

Fig. 3 Iberian or Iberian-Guanche inscriptions at the Island of Fuerteventura with naviform lines.

A) Inscriptions on the rock. B) The same inscriptions naviform symbols, marked so that they are better seen. C) Inscriptions and navi form lines out of the rocky context (Arnaiz-Villena et al. 2015).

Furthermore, the Iberian inscriptions of Lanzarote and Fuerteventura, as seen in Figure 3, are, in many times, surrounded by naviform lines, which are a characteristic of the Iberian inscriptions of the Iberian Peninsula, particularly at Pyrenees rocks (Fig. 4).
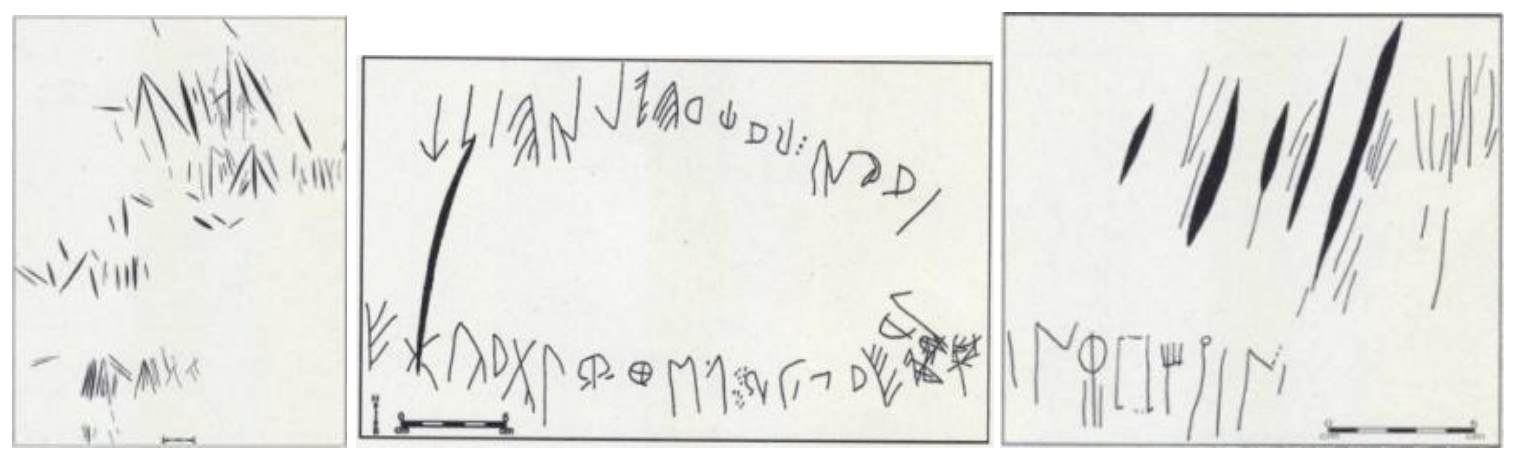

Fig. 4 Group of Iberian inscriptions with naviform lines in La Cerdaña (Pyrenees of Gerona). A) Naviform inscriptions alone. B) and C) Naviform inscriptions associated with Iberian inscriptions (Arnaiz-Villena et al. 2015).

As can be seen in the following figure (Fig. 5), this Iberian-Guanche or Iberian script is different from the Libyc-Berber inscriptions of the Canary Island archipelago and North Africa. 


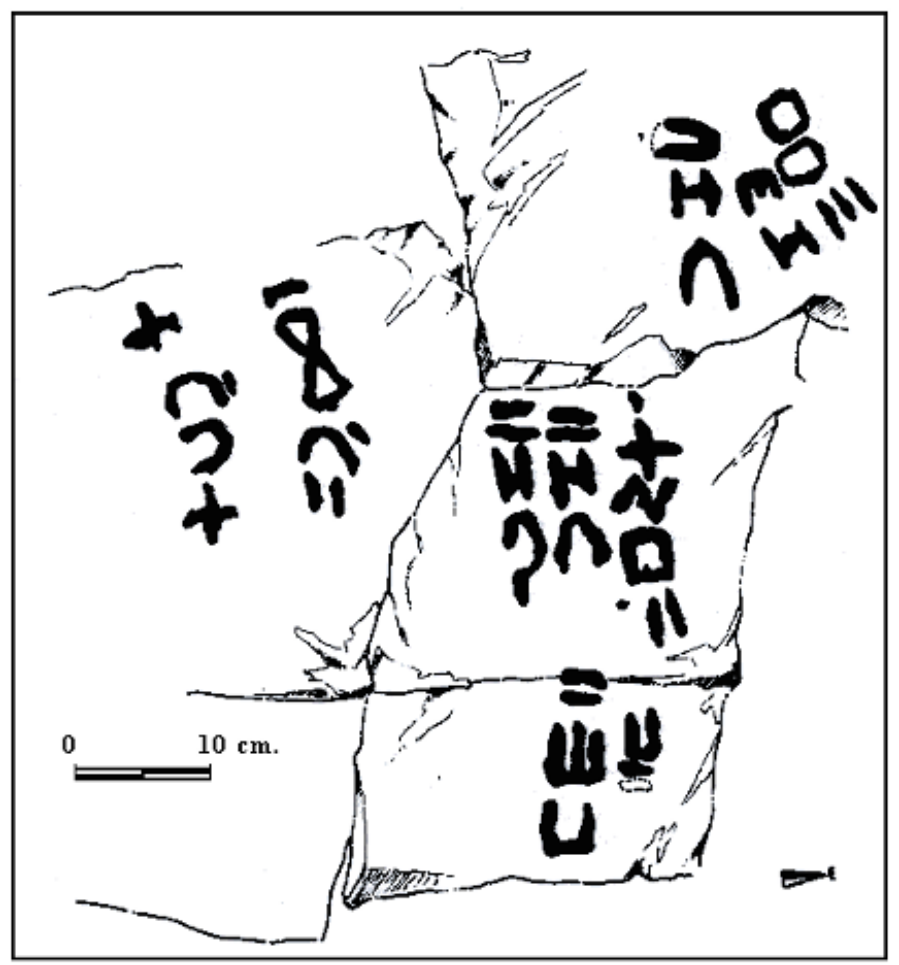

Fig. 5 Berber inscriptions from the Canary Islands on the island of El Hierro (Arnaiz-Villena et al. 2015).

\section{Material and Methods}

Therefore, we made transcriptions of the Iberian-Guanche inscriptions found at Canary Islands and also a translation proposal, as represented in the following figure, based on the Basque translation of the prehistoric Iberian, using a phonological and semantic methodology (Arnaiz-Villena and Alonso-Garcia 2001). For further methodology details, see (Arnaiz-Villena et al. 2019a; 2020).

Several photographs were taken at La Palma in various places distributed throughout the island. This type of linear incised inscriptions is found in many stations throughout the island mixed with the classic spiral drawings; sometimes the typical Atlantic spirals are super-scripted (incise ones being older) and other times the incised lines are the super-scripted ones (Pais-Pais 2019; Arnaiz-Villena personal observation). Photographs were taken with a Sony Camera Cybershot 14.1 Megapixels Carl-Zeisslens Vario-Tessar. Coordinates and azimuths were calculated as described in Arnaiz-Villena et al. (2019a). 


\begin{tabular}{|c|c|c|c|}
\hline $\begin{array}{l}\text { Fuerteventura's } \\
\text { Scripts }\end{array}$ & Iberian-Levantin Transcription & Translate to Basque and Spanish & Translate to English \\
\hline AVIVYAXYHSAN & KAMMBAMMKAMMOSKAN & $\begin{array}{l}\text { KAMU-AMA-ABA-MAMA-AKA-MAMA-OS KAN } \\
\text { Difunto de la madrecita dormido (en) la sepultura, madrecita del más allá }\end{array}$ & $\begin{array}{l}\text { Little Mother's deceased sleeping in the } \\
\text { sepulcher, Little Mother from afterlife }\end{array}$ \\
\hline IVSIIII'I & BAMSBABABABABA & $\begin{array}{l}\text { ABA-AMA-SABAI-BUBA-BUBA } \\
\text { En el interior (de) la tumba de la madre dormido dormido }\end{array}$ & Inside the Mother's tomb sleeping sleeping \\
\hline$\Lambda|x|$ & (I)LKAMBA & $\begin{array}{l}\text { IL-KAMU-ABA } \\
\text { Difunto dormido (en) la sepultura }\end{array}$ & Deceased sleeping in the sepulcher \\
\hline$(A V \wedge S$ & KEKAMLS & $\begin{array}{l}\text { KAKA-AMA-LUZE } \\
\text { Despojos de la madre (en) el abismo }\end{array}$ & Mother's remains in the Depths \\
\hline$A V I \mid A<A$, & KAMBABAKAKEKAKA & $\begin{array}{l}\text { KAMU-BUBA-BAKE-KAKA-AKA } \\
\text { Despojos del difunto dormidos (en) el sueño de la paz }\end{array}$ & $\begin{array}{l}\text { Deceased's remains sleep in the peace } \\
\text { dream }\end{array}$ \\
\hline$\lambda\left(V^{\prime \prime}\right)$ & KAKEMMMBA & $\begin{array}{l}\text { KAKA-MAMA-AMA-ABA } \\
\text { Difunto de la madrecita (en)la tumba de la madre }\end{array}$ & Little Mother's deceased in Her tomb \\
\hline प, & BABABALBA & $\begin{array}{l}\text { BUBA-BALTZ-ABA } \\
\text { Dormido (en) la tumba de la oscuridad }\end{array}$ & Sleeping in the Darkness tomb \\
\hline WWVWN/NYI & MKAMKMMMKAKAMMBA & $\begin{array}{l}\text { MAKA-MALLO-MAMA-MAKA-KAMU-AMA-ABA } \\
\text { Pecador (en) la colina de la madre, pecador sueño (en) la sepultura de la madre }\end{array}$ & $\begin{array}{l}\text { Sinner in the Mother's Hill, sinner dreamin } \\
\text { the Mother's Sepulcher }\end{array}$ \\
\hline WWVWNAYI & MKAMKMMMKAKAMMBA & $\begin{array}{l}\text { MAKA-MALLO-MAMA-MAKA-KAMU-AMA-ABA } \\
\text { Pecador (en) la colina de la madre, pecador sueño (en) la sepultura de la madre }\end{array}$ & $\begin{array}{l}\text { Sinner in the Mother's Hill, sinner dreamin } \\
\text { the Mother Sepulcher }\end{array}$ \\
\hline MUIA/XIVEARR\|AN & $\begin{array}{l}\text { KAMLBABAKALTABAMGEKA } \\
\text { RBABAKAM }\end{array}$ & $\begin{array}{l}\text { KAMU-IL-BUBA-KAL-ATA-ABA-AMA-GE-KAR-BUBA-AKA-AMA } \\
\text { Cada uno (de) los difuntos durmiendo el sueño (en) la sepultura de la madre de la } \\
\text { puerta; difunto de la madre durmiendo sin fuego }\end{array}$ & $\begin{array}{l}\text { Each one of the deceased sleeping the } \\
\text { dreamin the Sepulcher of the Mother of the } \\
\text { Door, Mother's deceased without fire }\end{array}$ \\
\hline$\Delta M V V \mid ' \| / N$ & MKAMLBARBABABABAKAM & $\begin{array}{l}\text { MAKA-AMA-IL-BARA-BUBA-BUBA-AKA-AMA } \\
\text { Difunto pecador de la madre, dormido dormido, venido a parar a la sepultura de la } \\
\text { madre }\end{array}$ & $\begin{array}{l}\text { Mother's sinner deceased, sleeping sleeping } \\
\text { in the Mother Sepulcher }\end{array}$ \\
\hline RADDIVA & RKARNANKA & $\begin{array}{l}\text { UR-KAR-BAN-AKA } \\
\text { Cada uno de los difuntos (en) las aguas de fuego }\end{array}$ & Each one of the deceased in the fire water \\
\hline
\end{tabular}

Fig. 6 Transcripts and proposals for translations from the Ancient Basque of the Iberian-Guanche inscriptions found in the Canary Islands.

See the following references for interpretation: (Pichler 1995; Arnaiz-Villena and Alonso-García 2001;

Arnaiz-Villena and Rey 2012; Arnaiz-Villena et al. 2019a, 2019b, 2020; http://basques-

iberians.blogspot.com.es/2014/02/la-ruta-del-atun-explicaria-las.html; http://basques-

iberians.blogspot.com.es/2013/11/las-escrituras-ibero-guanches-de.html ;

https://commons. wikimedia.org/wiki/File:Iberian-

Guanche inscriptions.pdf; chopo.pntic.mec.es/biolmol/publicaciones/Usko.pdf)

\section{Results}

Rocks found at St. Domingo Cemetery Steep Slope, also called "Calvary" (Garafía, La Palma) have been analyzed because they showed evident incised linear Iberian-Guanche scripts (Figs. 8 and 9), and also another rock (Fig. 7) deposited in Benahoarita Museum which comes from Fagundo, Lomo de las Tricias (Garafía) was studied. St Domingo rocks are currently (March 2020) moved from their initial placement by road works and other previous works carried out. The findings of spiral, meandering, circular and incised linear Iberian-Guanche petroglyphs (Pais-Pais 2019), indicate that St. Domingo Calvario Slope has an important cultural/religious site for the aboriginal inhabitants culture. Other La Palma Island Iberian-Guanche rock inscriptions were found to be picketed, not only in this place but throughout the entire island. 


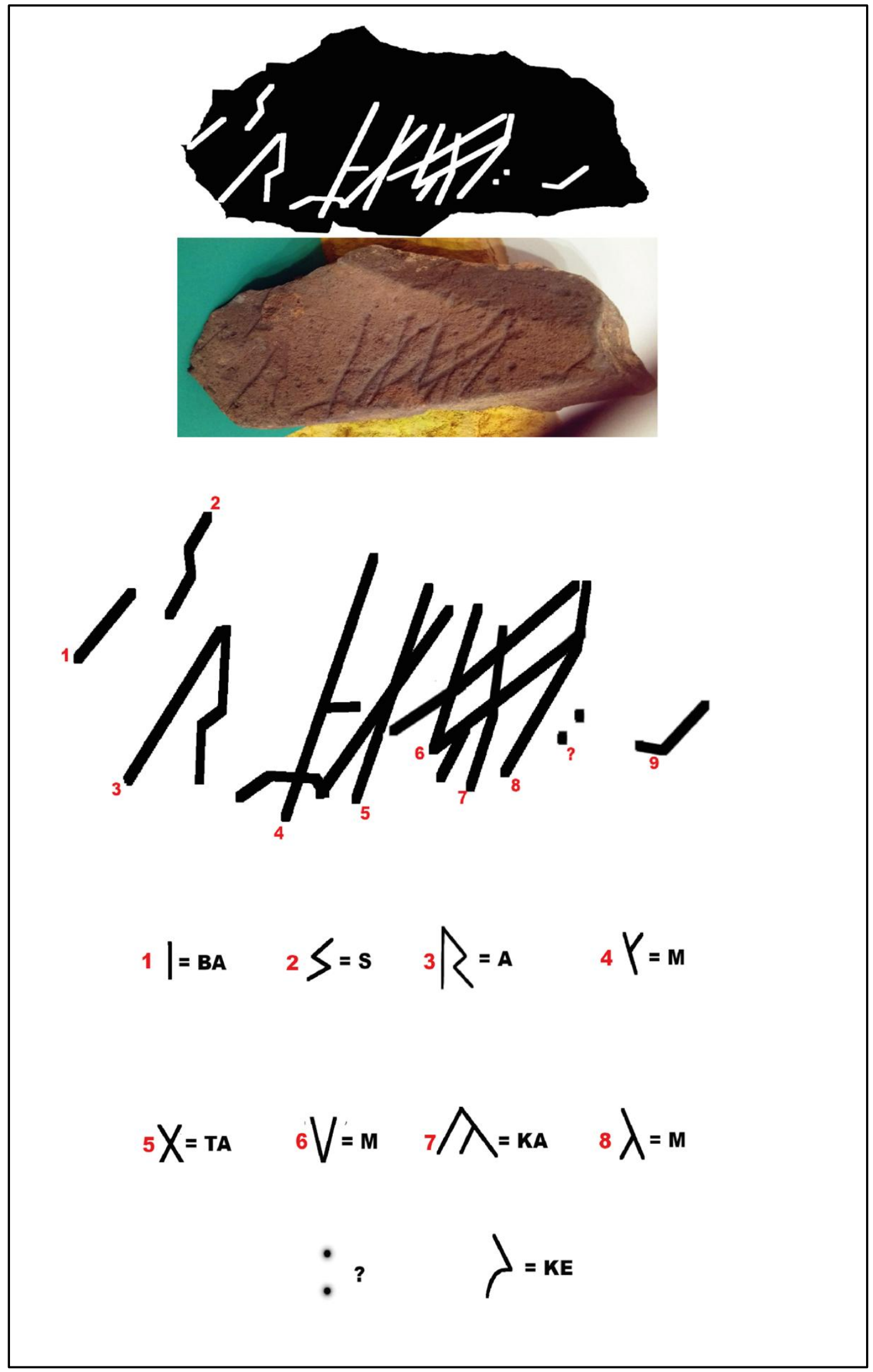

Fig. 7 Rock from Garafia, Lomo de Las Tricias (Fagundo)

(Photograph from the Benahoarita Museum by Arnaiz-Villena). Top: rock together with its black and white representation. Center: numbered identified Iberian semi-syllabary signs. Bottom: transcription of signs according to the Iberian semi-syllabary (Fig. 1). 

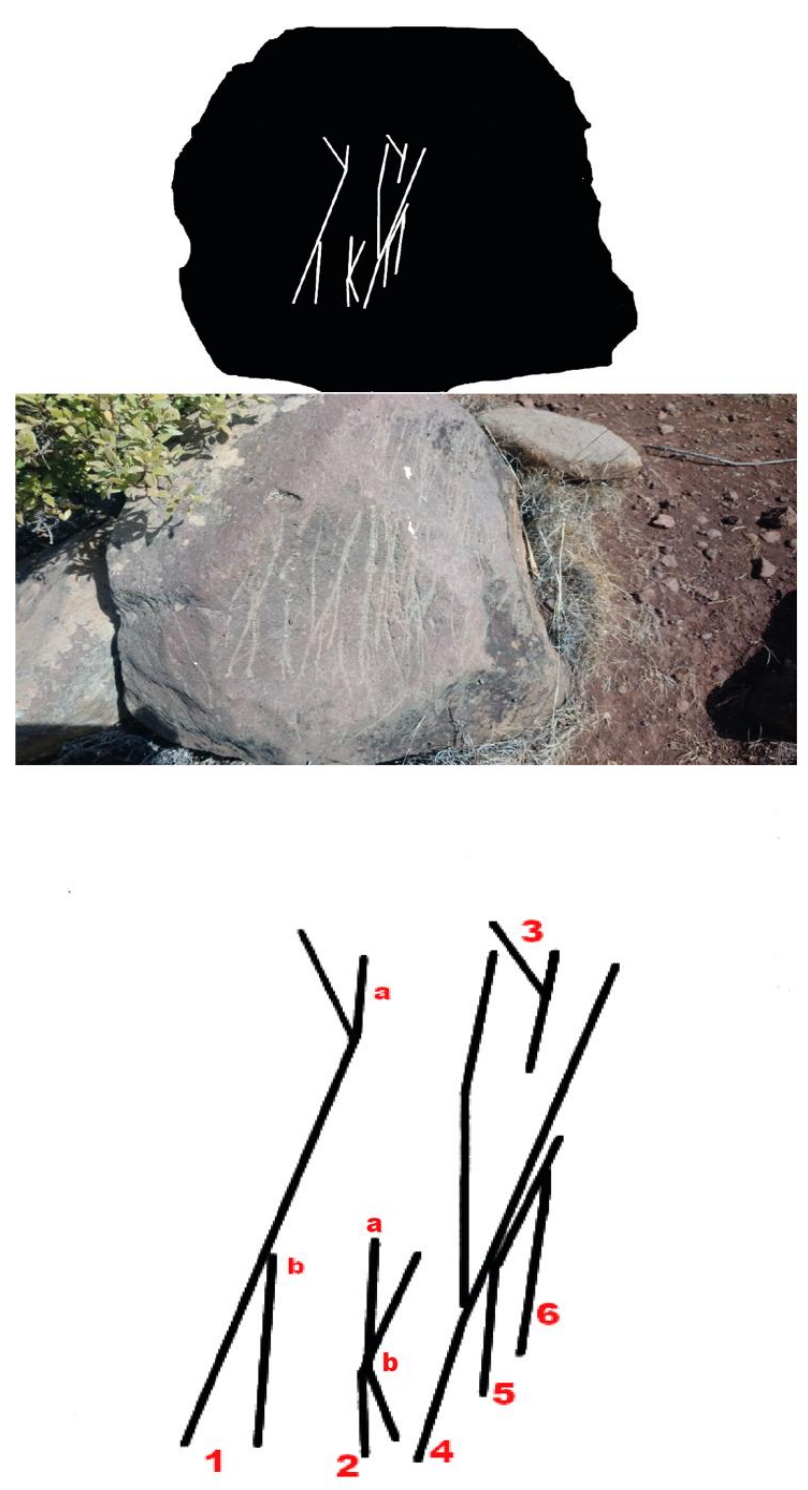

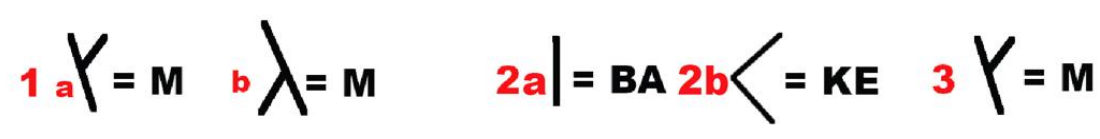

$4 \lambda=M \quad 5<=$ KE $\quad 6 \mid=B A$

Fig. 8 Rock from El Calvario de Santo Domingo, Garafía, La Palma.

(Photograph by Arnaiz-Villena). Top: rock together with its black and white representation. Center: numbered identified Iberian semi-syllabary signs. Bottom: transcription of signs according to the Iberian semi-syllabary (Fig. 1). 

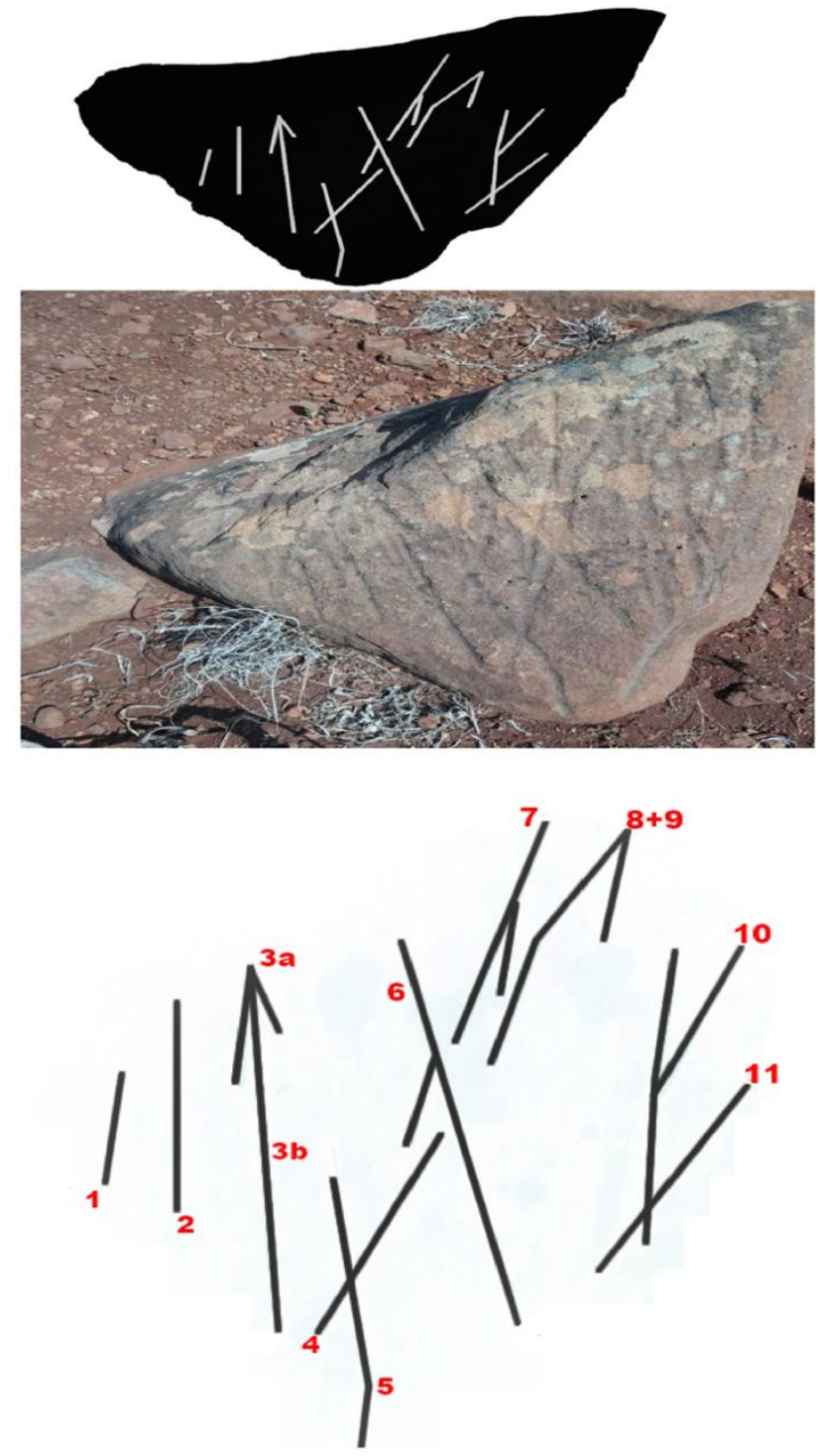

$1|=B A \quad 2|=B A \quad 3 a \widehat{=M} \quad 3 b|=B A \quad 4|=B A \quad 5\rangle=K E$

$$
{ }_{6} \lambda=m
$$

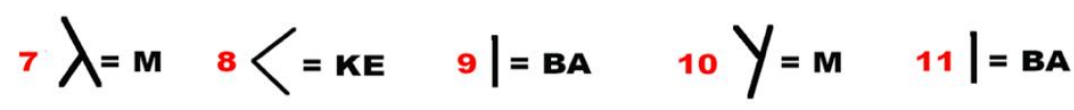

Fig. 9 Rock from El Calvario de Santo Domingo, Garafía, La Palma.

(Photograph by Arnaiz-Villena). Top: rock together with its black and white representation. Center: numbered identified Iberian semi-syllabary signs. Bottom: transcription of signs according to the Iberian semi-syllabary (Fig. 1). 


\section{Discussion}

\section{Translations of the Iberian-Guanche incised linear scripts from La Palma}

We described that incised linear Iberian-Guanche writing is present in all the Canary Islands (Arnaiz-Villena et al. 2019b). It was noticed that linear scripts similar to these in Lanzarote and Fuerteventura existed in La Palma Island, although without many details and without affiliation hypothesis (Pais-Pais and Perera 2011; Pais-Pais 2019). Both in Lanzarote (Arnaiz-Villena et al. 2020) and Fuerteventura (Fig. 6), and in Tenerife (Arnaiz-Villena et al. 2019c), the meanings of the proposed translations of this type of Iberian-Guanche inscriptions are very similar: invocations to "Ama", the Neolithic mother of Europe (Gimbutas 1991) who is profusely represented in Europe, the Mediterranean, Malta and also in the Canary Islands (Arnaiz-Villena 2019c); "Aka", the dead or deceased; "Bake", which takes the meaning of "Peace" (Figs. 10, 11 and 12); "Ata", the "Door" to another World. Actually, we are invariably encountering epitaphs similar to the Christian RIP ("Requiescat in Pace" or "rest in peace" the dead). Obviously, the old religion of the Mother of Gimbutas was replaced by other patriarchal ones that still exist.

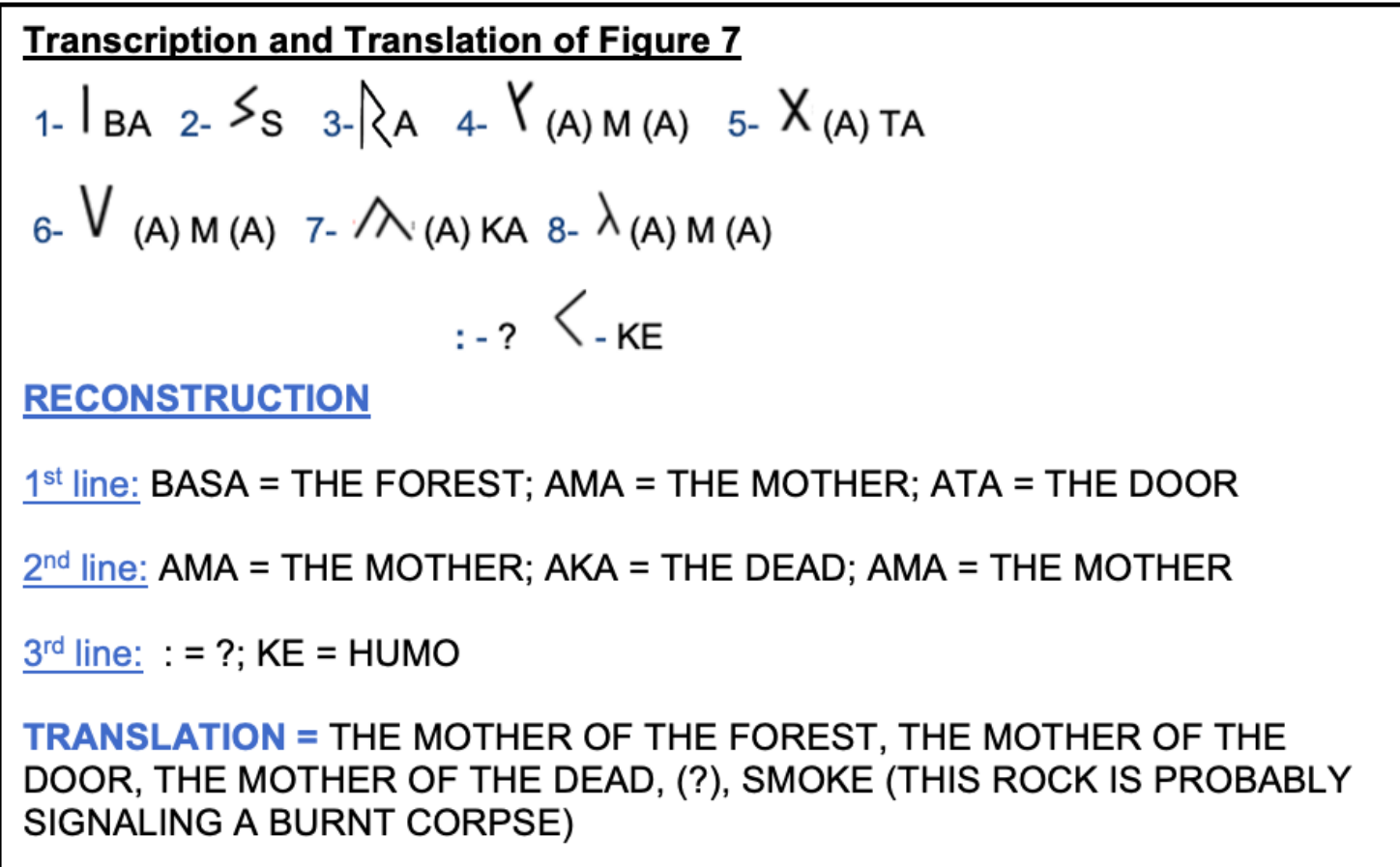

Fig. 10 Transcription and translation hypothesis of Figure 7. 


\section{Transcription and Translation of Figure 8}

A. 1a- $\left.y_{M \text { 1b- }} \lambda_{M \text { 2a- }}\right|_{B A ~ 2 b-}<K E$

B. 3- $Y_{\text {M 4- }} \lambda_{\text {M 5- }}<$ KE 6- $I_{\text {BA }}$

RECONSTRUCTION

The rock is displaced from its initial site. Central word is BAKE (2) and probably has the same reading starting from either left or right (repeated).

$\mathrm{A}(\mathrm{LEFT} \rightarrow \mathrm{RIGHT})$

AMA = THE MOTHER; AMA = THE MOTHER; BAKE = PEACE

TRANSLATION = THE MOTHER, THE MOTHER IN PEACE!

$\mathrm{B}(\mathrm{RIGHT} \rightarrow \mathrm{LEFT})$

TRANSLATION = PEACE IN THE MOTHER!

Fig. 11 Transcription and translation hypothesis of Figure 8.

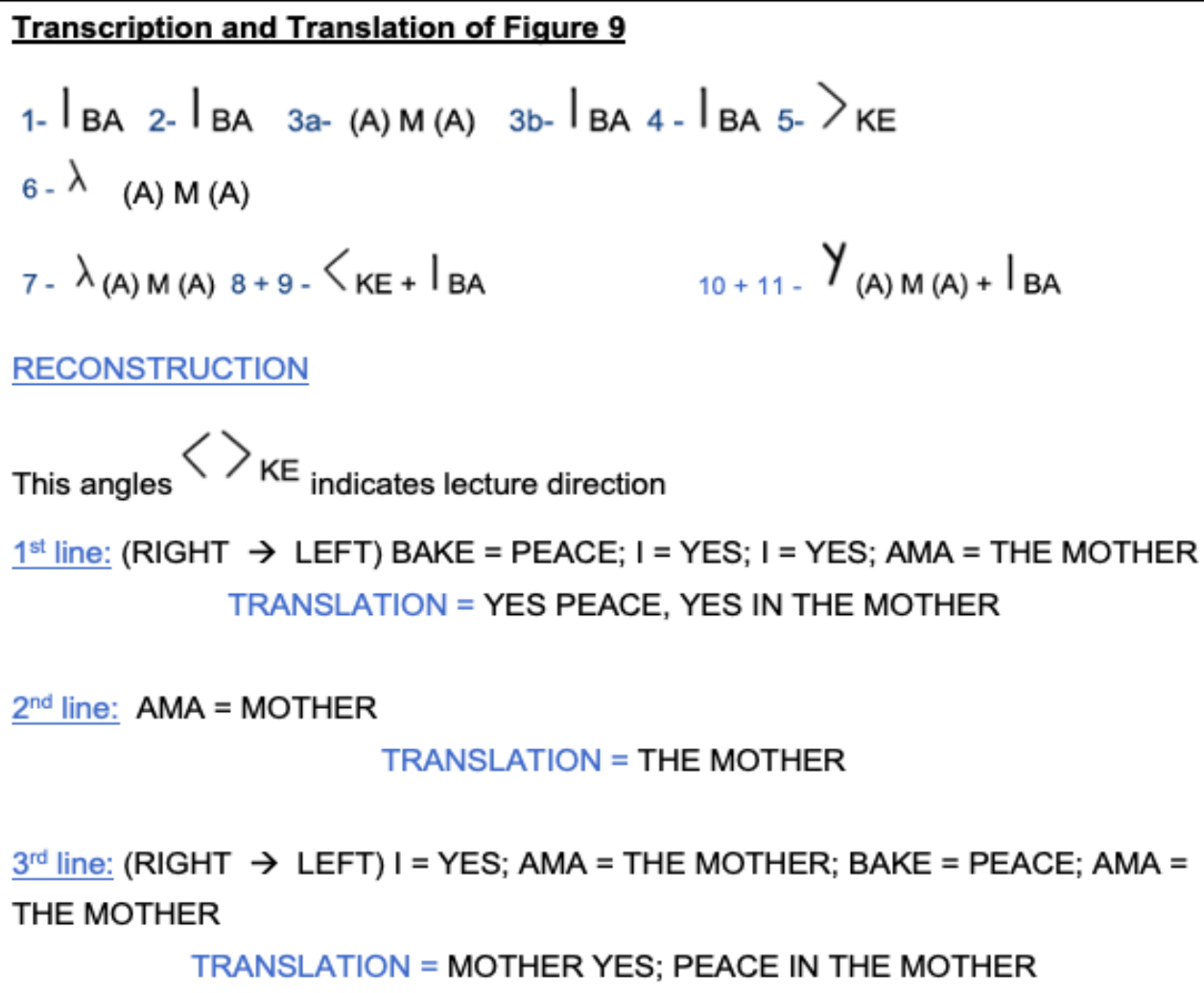

Fig. 12 Transcription and translation hypothesis of Figure 9. 
The simple hypothesis of transcription and translation through Basque sound and meaning (phonetic and semantics) on islands as distant as La Palma and Lanzarote/Fuerteventura (Fig. 6) or Tenerife (Arnaiz-Villena et al. 2019b; 2019c) seems to confirm that our methodology is correct.

1) The writing system on studied rocks of the Canary Islands is the Iberian semisyllabary (Fig. 1).

2) The coincidence of phrases, semantics and general standard funeral ritual words on translations in all Canary Islands indicates the existence of a common culture and classical cultures.

3) Invocations to the Goddess ("Ama") would take us to the times of the prepatriarchal religion of Marija Gimbutas (previous to 3,000 years BC) and probably to the Fat Neolithic Goddesses of Malta (Arnaiz-Villena et al. 2019a) and from other parts of the Mediterranean, possibly including Africa and the Canary Islands as well (Diosa Tara, Museo Canario:

http://www.elmuseocanario.com/regresoidolotara/), and Fat Goddesses found at La Fortaleza (Ansite, Gran Canaria Island) (Moreno Benitez 2020). The preclassical "Quesera" of Lanzarote, the piles/pyramids of La Palma (Pais-Pais 2019) or Tenerife (Sanchez Romero et al. 2020) and the nearby Western Sahara (Clarke and Brooks 2018), lead us to believe that these Iberian-Guanche rock scripts could be older than the first millennium BC and, therefore, to the rock scripts of Iberia and southern France written with Iberian semi-syllabary, which are dated (perhaps arbitrarily) below the first millennium BC. Other similar details have already made us affirm that the prehistoric Canarian culture could be megalithic (Arnaiz-Villena 2019b).

4) The fact that the incised inscriptions sometimes have circular and rounded motifs superimposed (Pais-Pais 2019; Arnaiz-Villena, personal observation), which are common to the megalithic Atlantic Cornice, suggests that these Iberian-Guanche incised lines are megalithic.

5) The entire La Palma Island is covered by Iberian-Guanche carved rock panels (Pais-Pais 2019). It indicates, like in Lanzarote and Fuerteventura Islands (Pichler 1995; 2003), that they are manifestations of Canarian aborigines. The 
other islands, including Tenerife (Arnaiz-Villena et al. 2019c) have yet to be studied in depth in terms of Ibero-Guanche scriptures.

6) Theories of non-navigation between Islands are not credible because of present and others findings at the Canary Islands (Arnaiz-Villena et al. 2019b).

\section{Origin of Iberian inscriptions}

Therefore, Iberian rock inscriptions are found far from the Iberian Peninsula and France, at Canary Islands; some of them seem to have been performed in an older time than the Libyc-Berber inscriptions of North Africa and the Canary Islands, since the Iberian inscriptions that we have called Iberian-Guanches (and others call LatinCanarian) are often found on the rocks together with the Libyc-Berber inscriptions and these ones have sometimes been written on top of the Iberian inscriptions. Also, some Atlantic megalithic La Palma spirals and other drawings are written on Iberian-Guanche inscriptions, which may be older or contemporary at least (Pais-Pais 2019; ArnaizVillena, personal observation)

The Iberian-Guanche inscriptions were most likely made by native Canarians (Guanches), since in Lanzarote and Fuerteventura there is a great density of these inscriptions. Also, they are almost always found in high places and away from the coast, such as on the top of hills and volcanoes.

We have classified the Guanche language as a Usko-Mediterranean language in which there are several related languages (living and dead) and which are represented in the following figure, where the old Sardinian is missing (Fig. 13):

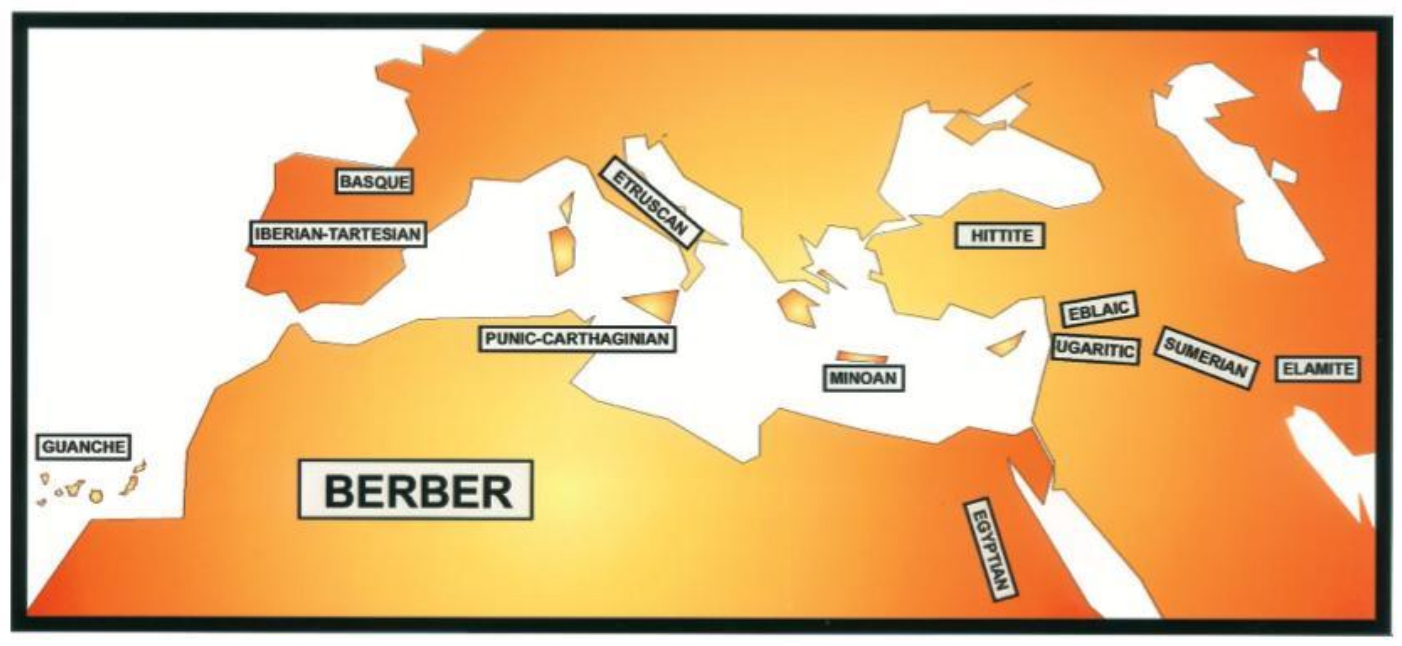

Fig. 13 Usko-Mediterranean living and dead languages. Was Iberian initially written by Guanches or other North African populations? (Arnaiz-Villena et al. 1999, 2001) 
The problem arises as to whether the Iberian inscriptions of the Canary Islands were made in a previous time that those of the Iberian Peninsula. Probably the answer to this question lies under the sands of the Sahara Desert (Fig. 14).

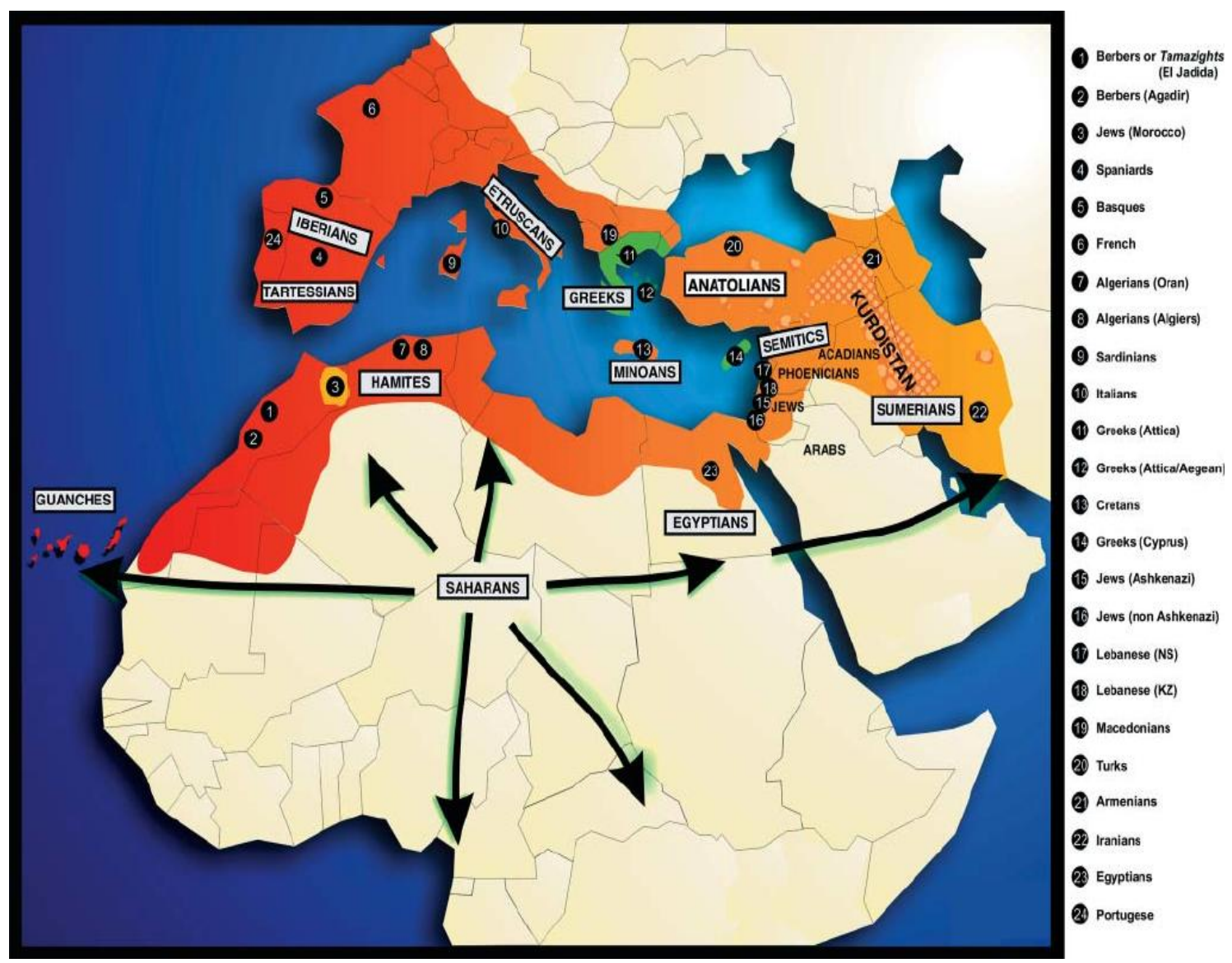

Fig. 14 Postulated Saharan migration.

Ancient Mediterranean populations are within squares. Today's populations are in circles. Kurds (30 million) live in the area marked with pink dots: Kurdistan (Arnaiz-Villena et al. 2002).

The Saharan hypothesis of genetic and cultural migration: other writings of the Sahara and the Atlantic coast

It has been shown that about 10,000 years ago what is now the Sahara Desert was full of lakes and rivers: infrared satellite photographs have shown it. A slight variation in the Earth axis of rotation caused the area to suffer a relatively rapid desertification (ArnaizVillena et al. 2001; 2020).

This possibly caused a migration of people (thus genes) and cultures in all directions, as represented in the previous figure. This meant that, at one point, the Mediterranean Sea Basin was during thousand years densely populated and partly isolated by ice from the last Ice Age to the North and the Sahara Desert to the South. In 
this context, cultures that were born in Mediterranean Area were not originated by heritage of Greece or Rome, as it is taught, but also the product of contributions from all other southern North African populations (Berbers), and also by people living from the East to North India (Middle East, Persia etc.), North (South and Central Europe) and West (Iberia, Africa, British Isles, Canary Islands, North Africa). It must be taken into account that in the Megalithic Culture extant in Atlantic Africa and Europe, large Megalithic monuments of very difficult construction were built by 2,000 years before the classical Egypt pyramids (Arnaiz-Villena et al. 2019b).

Finally, the Canarian Archipelago has been inhabited in ancient times by Mediterranean and Atlantic peoples, as we have shown in our work (Fig. 15) (ArnaizVillena and Alonso-García 2001; Arnaiz-Villena and Rey 2012; Arnaiz-Villena et al. 2015; Arnaiz-Villena et al. 2017; Arnaiz-Villena et al. 2019b; Medina and ArnaizVillena 2018a; 2018b; http: //basques-iberians.blogspot.com.es/2014/02/la-ruta- deltun-explicaria-las.html; http://basques-iberians.blogspot.com.es/2013/11/las-escrituraibero-guanches-de.html; https://commons.wikimedia.org/ wiki / File: IberianGuanche_inscriptions.pdf; chopo.pntic.mec.es/biolmol/publicaciones/Usko.pdf).

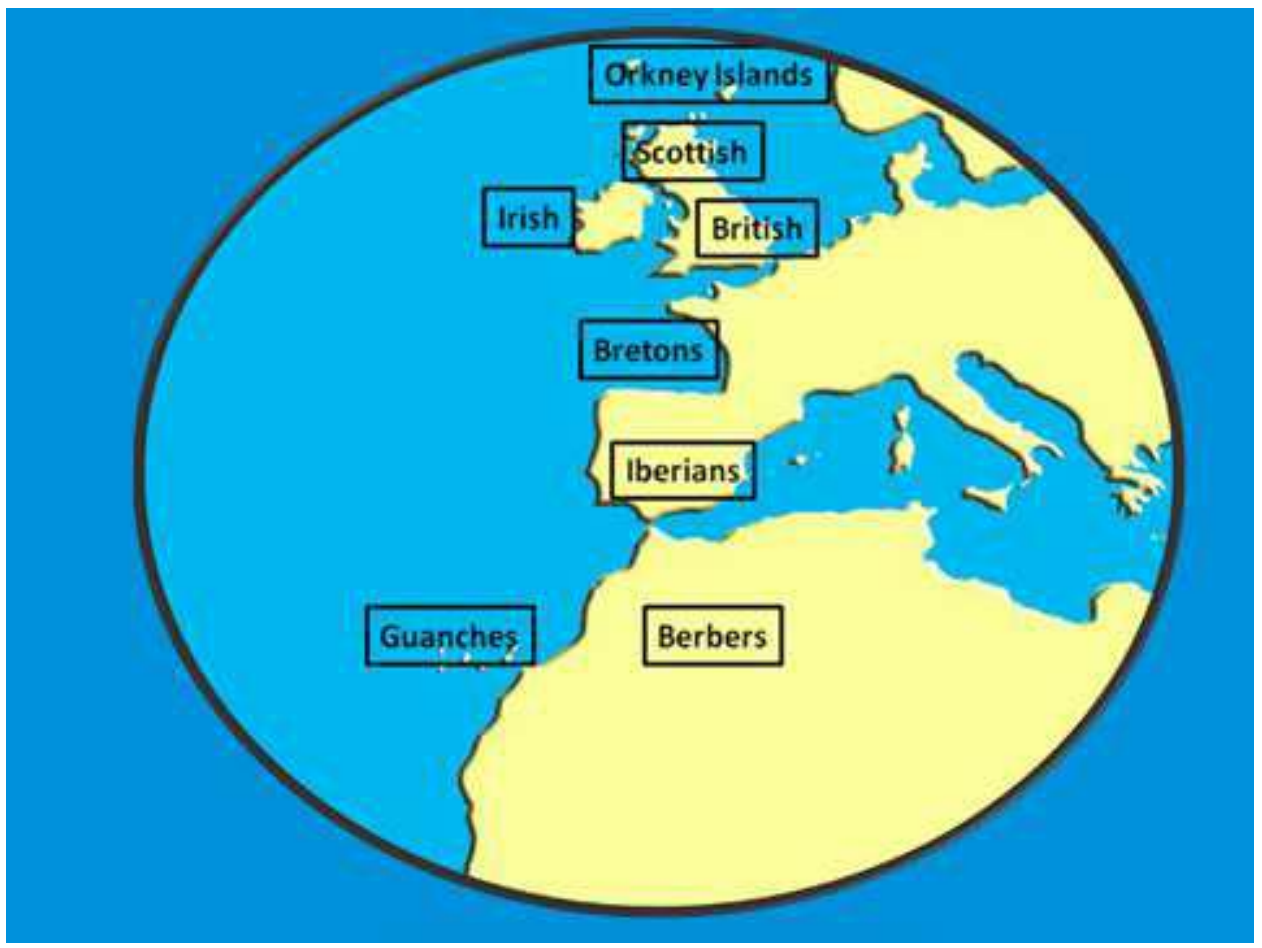

Fig. 15 Genetically related Atlantic populations (Arnaiz-Villena et al. 2017). 
Conflicts of Interest: The author declares no conflict of interest.

\section{Acknowledgement}

We thank Complutense University from Madrid (Spain) for its support and Enrique

Garcia Moreno for his help.

\section{References}

Arnaiz-Villena A. and Alonso García J. 2001. Egipcios, Bereberes, Guanches y Vascos. Madrid, España: Visión Libros.

Arnaiz-Villena A., Martinez-Laso J., Alonso-García J. 1999. Iberia: population genetics anthropology and linguistics. Human Biology 71: 725 - 743.

Arnaiz-Villena A., Martinez-Laso J., Alonso-García J. 2001. The correlation between languages and genes: the Usko-Mediterranean peoples. Hum. Immunol. 62: 1051 - 1061.

Arnaiz-Villena A., Gomez-Casado E., Martinez-Laso J. 2002. Population genetic relationships between Mediterranean populations determined by HLA allele distribution and a historic perspective. Tissue antigens 60: 111 - 121.

Arnaiz-Villena A. and Rey D. 2012. Iberian Tartessian scripts/graffiti in Iruña-Veleia (Basque Country North-Spain) :findings in both Iberia and Canary Islands, Africa. Int. J. Mod. Anthrop. 1: 24 - 38.

Arnaiz-Villena A., Muñiz E., Campos C., Gomez-Casado E., Tomasi S., MartinezQuiles N. et al. 2015. Origin of Ancient Canary Islanders (Guanches): presence of Atlantic/Iberian HLA and Y chromosome genes and Ancient Iberian language. Int. J. Mod. Anthrop. 8: 67 - 93.

Arnaiz-Villena A., Carballo A., Juarez I., Muñiz E., Campos C., Tejedor B. et al. 2017. HLA Genes in Atlantic Celtic populations: Are Celts Iberians? Int. J. Mod. Anthop. 10: $50-72$.

Arnaiz-Villena A., Medina M., Lopez-Nares A., Rodriguez-Rodriguez J., Ruiz-DelValle V. 2019a. Cart-ruts in Lanzarote (Canary Islands, Spain) and Malta: first evidence of dating supported by dated ceramics. Int. J. Mod. Anthrop. 2: 115 - 140.

Arnaiz-Villena A., Lopez-Nares A., Juárez I., Ruiz-Del-Valle V., Callado A., H-Sevilla A., Gomez-Casado E. 2019b. "Latín" rock scripts in Canary Islands are ancient Iberian inscriptions (Iberian-Guanche). A story of forgotten genetics, scripts, pyramids and other prehistoric artifacts. Int. J. Mod. Anthrop. 12: 189 - 212. 
Arnaiz-Villena A., Lopez-Nares A., Ruiz-Del-Valle V., Juárez I., Bello A., Callado A., et al. 2019c. The Rock of the Dead: A New" Latin" or "Iberian-Guanche" Inscriptions found in Tenerife Is. (Canary Islands, Spain). Int. J. Mod. Anthrop. 2: 214 - 232.

Arnaiz-Villena A., Medina M., Ruiz-Del-Valle V., Lopez-Nares A., RodriguezRodriguez J., Suarez-Trujillo T. 2020. The Ibero-Guanche (Latin) rock inscriptions found at Mt. Tenezara volcano (Lanzarote, Canary Islands, Spain): A Saharan hypothesis for Mediterranean/Atlantic Prehistory. Int. J. Mod. Anthrop. 2 (13): 140 162

Clarke J. and Brooks N. 2018. The Archaeology of Western Sahara. Oxford, Reino Unido: Oxford Books.

Gómez Moreno M. 1949. Las lenguas hispánicas. Discurso de recepción en la Real Academia Española. Madrid, España.

Gómez Moreno M.1962. La escritura bardulo-turdetana. Madrid, España: Primitiva Hispánica. Madrid.

Gimbutas M. 1991. Diosas y Dioses de la vieja Europa, 7000-3800 a. C. Madrid, España: Itsmo.

Hernandez-Perez M. S. 1972. Contribución a la Corte arqueológica de la isla de La Palma (Canarias). Anuario de Estudios Atlánticos, Vol. 1, 18.

Medina M. and Arnaiz-Villena A. 2018a. A Lunisolar Prehistoric Calendar in Lanzarote Island: "La Quesera" (Cheeseboard) from Zonzamas. In. J. Mod. Anthrop 2: 147 - 161.

Medina M. and Arnaiz-Villena A. 2018b. The Moon: in Prehistoric Lunisolar Rock Calendar "Quesera"-Cheeseboard- at Lanzarote, Canary Islands, Spain. Int. J. Mod. Anthrop 2: 182 - 212.

Moreno Benitez M.A. 2020. El tiempo perdido. Ed. Tibicena Publicaciones. Las Palmas de Gran Canaria (Canary Islands, Spain).

Pais-Pais F. J. 2019. Los petroglifos benahoaritas: símbolos de vida y fertilidad. Islas Canarias, España: Cabildo de La Palma.

Pais-Pais F. J. 2020. Los benahoaritas. Casa Colón, Islas Canarias, España.

Pais-Pais F. J. and Perera M. A. 2011. Expresiones rupestres prehispánicas de ténica de ejecución incisa en La Palma. Revista de Estudios Generales de la Isla de La Palma, 5: $443-475$.

Pichler W. 1995. Neue Ostinsel-Inschriften (latino-kanarische Inschriften) auf Fuerteventura. Almogarén, XXVI: 21 - 46.

Pichler W. 2003. Las inscripciones rupestres de Fuerteventura. Puerto del Rosario, España: Cabildo de Fuerteventura. 
Sánchez Romero G., Lopez Arencibia S., Bello A., Sarmiento Pérez M. 2020. Una pirámide/calendario solar Guanche en el norte de Tenerife: referencias históricas, características, origen y función. Almogaren 51: 5 - 55 .

To cite this article:

Arnaiz-Villena A., Suárez-Trujillo F., Ruiz-del-Valle V., López-Nares A., Pais-Pais F.J. 2020. The Iberian-Guanche rock inscriptions at La Palma Is.: all seven Canary Islands (Spain) harbour these scripts International Journal of Modern Anthropology. 2 (14): 318 - 336

DOI: http://dx.doi.org/10.4314/ijma.v2i14.5

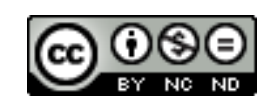

This article, as all articles published in this journal, is under The Creative Commons Attribution:

Attribution-NonCommercial-NoDerivatives 4.0 International (CC BY-NC-ND 4.0).

https://creativecommons.org/licenses/by-nc-nd/4.0/ 